\title{
An Application for Alumni of Soegijapranata Catholic University
}

\author{
Hanna Mulianawati \\ Information System Department, Computer Science Faculty, \\ Soegijapranata Catholic University \\ email: hannajezz@yahoo.com \\ Ridwan Sanjaya \\ Information System Department, Computer Science Faculty, \\ Soegijapranata Catholic University \\ FX Hendra Prasetya \\ Information System Department, Computer Science Faculty, \\ Soegijapranata Catholic University
}

\begin{abstract}
Sometimes it's hard for the university to get the information about their own alumni after the graduation ceremony. The situation of the alumni is also the same. They felt difficult to reach their university after they got a job. Some services and documents are still needed by the alumni for any reason. In fact, people nowadays live with their smartphone really closely. The smartphone could help people to get information and services while keeping them close to their community. The mobile application should be built to connect alumni and university through a smartphone via information sharing about job vacancy and providing some university's services. Some methods are used in the process of mobile application development, such as designing the application, programming, testing, and launching. Interview and survey are done to know the responses in using the application. The conclusions of the research are the application could help the alumni to get information and services, the university is able to gain the updated data of their alumni, and make both of them closer.
\end{abstract}

Keyword - android application, job vacancy, rss feed, soegijapranata catholic university, tracer study, university alumni.

\section{INTRODUCTION}

The technology nowadays especially in the field of information and communication has grown rapidly and it is still growing until today. The use of smartphone is kept increasing, therefore, the smartphone is one of the megatrends. According to Koskinen, smartphone these days is not only just a tool for communicate, but more than that, it is a symbol of economic and cultural systems, a fashion model, and a lifestyle[1]. This state boosts the developers to be more innovative in creating an application so that the user's needs can be fulfilled through the application.

Another thing that happening now especially in the developing country like Indonesia, many people are unemployed. Unemployment has many terms that describe and define the meaning of the word. Some terms about unemployment that related are frictional unemployment and open unemployment. Frictional unemployment means the situation where unemployment occurs because of the difficulties to bring the employer and the job seeker together. Open unemployment occurs when workers are not working or even trying to find work. Many factors that cause open unemployment, such as the mismatch between the applicant's abilities and the skills required by the employers, insufficient or non-existent jobs, or even a low willingness to work[2]. The data from BPS (Badan Pusat Statistik) said that Indonesia has an unemployment rate in 
number 5.5\% (February 2016)[3]. However, the ideal rate of unemployment number for a country is at range $3 \%$ or not more than 4\%[2][4]. Another reason for unemployment is the lack of information about the job vacancy. So creating a way to provide the information easily can reduce the unemployment. These days, people are often still looking for job information through newspapers, radio or other media. Some people even come to a particular place or company to ask directly about the job vacancy. This might not only happen in the society but also happen among the alumni. In this modern era, alumni should be able to get information through the application, so there is no need to waste a lot of energy to find information about work, use time efficiently and can reduce the level of open unemployment or frictional unemployment.

In university life, for most alumni, the campus is just a part of their history. The relation between them and the university itself seems end after the graduation celebration. Legalizing for diploma or certificate becomes hard or maybe impossible for them who live in other city or even abroad. Thoughts or desire to share an experience or a chance to work together or job opportunity may not be delivered well. The university itself facing a difficulty to collect the data of their own alumni. The data that university needs such as current address, phone, email, and also a current job as well as the position. This usually happens because alumni do some changes to their email or phone or even changing address without updating the data that exist at the university. Those data are important for the university for thing like university accreditation.

There are several goals in this research. First, creating a design of the application to help alumni find job vacancies information easily. Second, formulate the feature of application to provide university's services for the alumni. Third, find a way to implement the feature on the Android-based application. Last, to acquire a way to help university obtain graduate's data through the application.

\section{LITERATURE REVIEW}

\section{A. Application}

The application is a program that can be downloaded to a smartphone. There are two kinds of a smartphone, static and dynamic. A static smartphone is a smartphone that can be defined as a reference and used for describing a service or product, while a dynamic one is a smartphone that more likely engaging or involving the user with their phone and they can communicate with the platform that gives response directly[5].

\section{B. Android}

Android is a mobile operating system based on Linux that has been modified. Established by the same name start-up company called Android Inc. at first. But then in 2005, Google took over or more precisely they bought the name and the developers as well. Google wanted Android to be the one in the world as a mobile operating system that is free and open for everyone. Therefore, Google released the source code under the Apache License so that all people are able to modify and develop the code as their own wish. The vendors of the smartphone also use this way to add an ownership extension to their Android system, with the intention to differentiate their product from other. Up to now, Google has 12 version of Android and each of them has unique version name that comes from food or drinks name. Those versions are Android 1.6 Donut, Android 2.1 Éclair, Android 2.2 Froyo, Android 2.3 Gingerbread, Android 3.0 Honeycomb, Android 4.0 Ice Cream Sandwich, Android 4.1 Jellybean, Android 4.4 KitKat, Android 5.0 Lollipop, Android 6.0 Marshmallow, Android 7.0 Nougat, Android 8.0 Oreo.

Android has a digital store like another mobile operating system, called Play Store. The user can buy an application or even download for free application through the store. A large number of user that used Android operating system gave impact to the number of application that released at Play Store. The latest amount application at Play Store reached 2.868.591 (updated 20 April 2017)[6]. 


\section{Android Studio}

Android Studio is an official IDE (Integrated Development Environment) that used for developing the Android-based application. This software requires a component named JDK (Java Development Kit) to run it. Hence, the language used for programming is Java language. Android Studio offers many features that facilitate the developers to use the software easily, such as run without building a new APK called "Instant Run" feature, availability to develop all Android devices, fast emulator, flexible Gradle system, and so on[7].

\section{Really Simple Syndication (RSS)}

RSS firstly found at 1999 by a company named NetScape. Till now the technology of RSS continues to grow and the latest version is RSS 2.0[8]. Nowadays, starting from a search engine, shopping sites, or even blogs, RSS becomes one of a famous web technology. RSS that stands for Really Simple Syndication, is an easy way to share or spread a real-time content. The first idea appeared when the visitors like a content on a site, but they didn't want to open the site every day just to check the availability of the new content. Simply, RSS somehow make the visitors subscribe to the site. The content of RSS is presented in the form of XML (eXtensible Markup Language) format. XML contains some structured data such as title, published date, author, and the main content or news [9]. RSS makes easy for a publisher to syndicate the news so that the other sites are able to spread and display the news for free. RSS also becomes a way for a publisher to advertise their news and spread the ideas exist in the news to the Internet easily[10].

\section{E. Tracer Study}

Tracer study is a survey of alumni from a university. Other terms for tracer study are "Follow-up Study", "Graduate Survey" or "Alumni Research". The target of tracer study is the alumni who already graduated several months or years. The aim of conducting tracer study is to obtain information about alumni with the intention to evaluate university or give training. The information can be used to measure and enhance or improve the quality of the institution. Therefore, the information sought is related to graduate's work, position, income as well as the relevance of knowledge and ability gained during learning at university with the reality at work.

\section{RESEARCH METHODOLOGY}

\section{A. Research Object}

According to Supranto, an object of a research can be in a form of a person, organization, business corps, or a thing[11]. And the object of this research is the alumni of Soegijapranata Catholic University. The sample is not less than 30 alumni.

\section{B. Research Location}

This research conducted at one of the units at Soegijapranata Catholic University named SSCC (Soegijapranata Student Career Center). SSCC is located on the $2^{\text {nd }}$ floor Mikael building.

\section{Data Collection Method}

The method that used for this research is quantitative research method, while the methods to acquire the primary data were interview and questionnaire. The interview was conducted to find out the process that done by the SSCC unit so far and to know what they need. The interview also looks for data on whether the application is right developed with the initial concept and whether the application helps the SSCC units to fulfill their need. The questionnaire was spread out through Google Form to gain the information after alumni used the application. The secondary data acquired from journals, books, and some articles on the internet.

\section{Application Development Method}

In the development process, some steps were done to create an application. The first step of application development was data collection. Data obtained through an initial interview with the head of SSCC. With the data, next step was making the concept of application. Once the application concept is complete, then the next step was to do the programming. The application program should be tested whether it can run well or not. If not, then there should be an improvement or 
correction of the programming process. If the app works well, then the app is published in the Play Store. After the publication was done, the questionnaires were spread to get data about the use of the application.

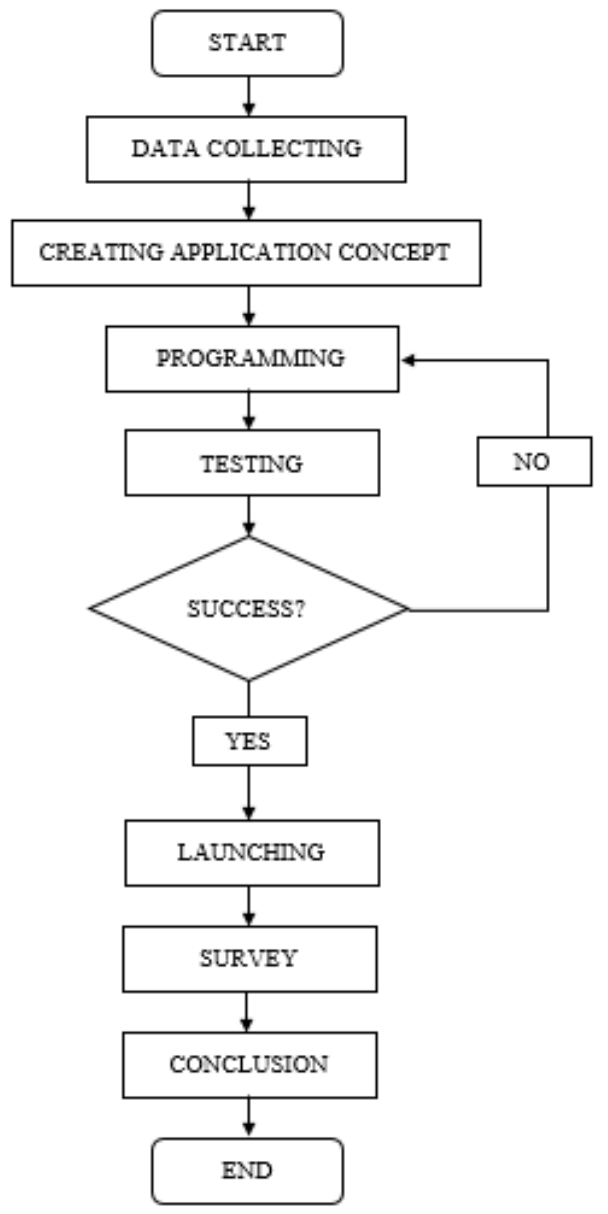

Figure 1. Flowchart of Mobile Application Development

\section{RESULT AND DISCUSSION}

\section{A. Application Development}

The application "Halo Alumni" is the second application under control of SSCC after "Unika Job Fair". The application was developed using Android Studio and the result is an application based on the Android operating system.

The operation of this application is very simple. Users only have to register at first by filling the form and after the registration process is done, the user can access the application content freely.

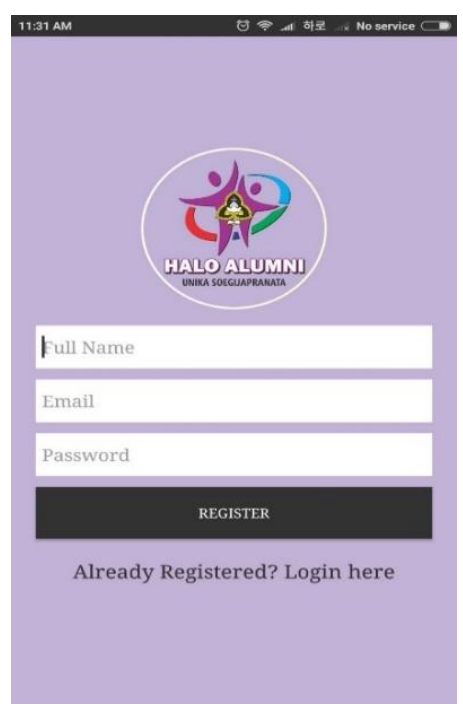

Figure 2. Registration Form

The information or data that filled by the alumni from this registration process will be stored in the database. The process of Log-In also used email and password from the same table.

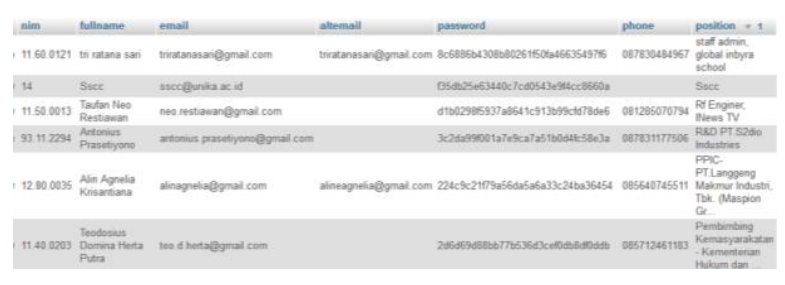

Figure 3. Database

The same table also used in the Profile menu, a menu that shows the personal data of the alumni and from that menu alumni are able to do the update. Some columns such as NIM, fullname, altemail, phone, and position are filled after the registration process when alumni update their personal data through the Profile menu. "Halo Alumni" has many other menus, some of them are Unika News, Entry Level, Mid-Level, Metamorfosa (Alumni Success Story), Ikasoepra (Alumni Community), Video, Survey Alumni (Alumni Survey), Ruang Diskusi Alumni (Alumni Discussion Room), and Digital Legalisir (Digital Legalization). Those menus are put in the navigation drawer with the intention that the user can easily change or choose the other menu while using the application. 


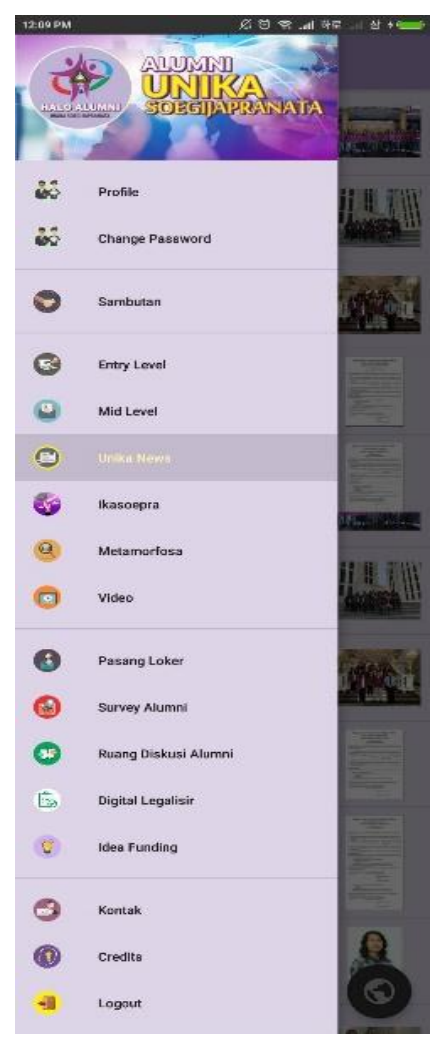

Figure 4. Navigation Drawer

Alumni are able to follow the updates from the university through some menus such as Unika News, Metamorfosa, Ikasoepra, and Video that have information about the university. The information about job vacancy is on the Entry Level and Mid-Level menu which obtained from the result of RSS website SSCC.

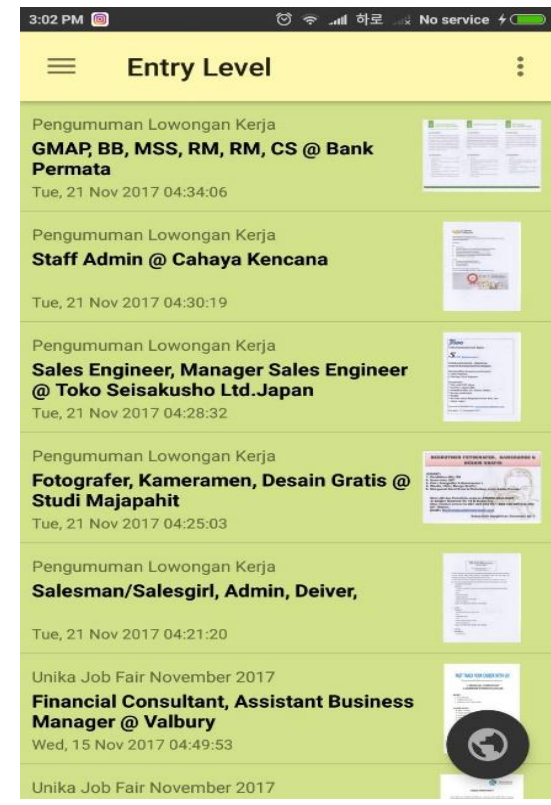

Figure 5. Entry Level Menu

The source of the vacancy information is not only from SSCC, but the alumni who already work can send or share the information about job vacancy to SSCC through the menu "Pasang Loker". Then SSCC team will check the vacancy and if it's valid, the vacancy will be displayed.

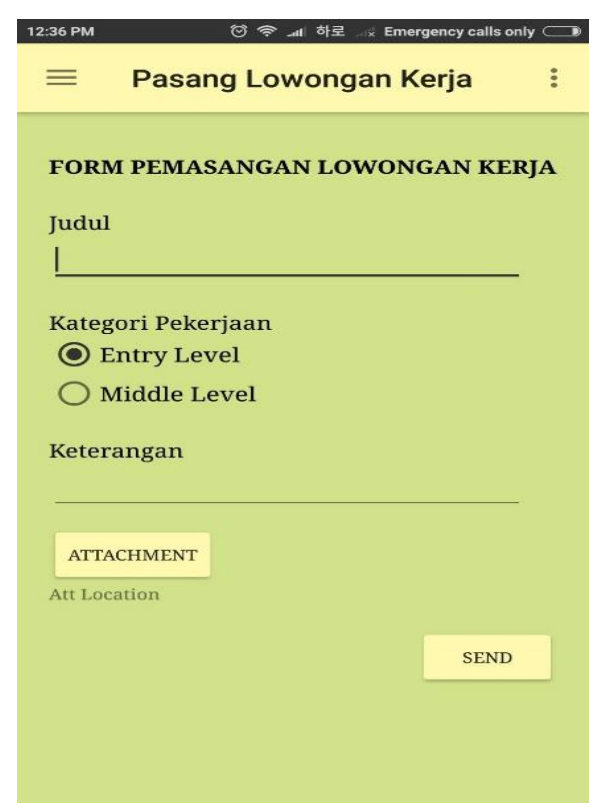

Figure 6. "Pasang Loker" Menu

One of the menus named "Survey Alumni" is used by SSCC to embed the link of Google Form to get alumni information related to tracer study. Link to the form later will be updated according to the requirement of SSCC.

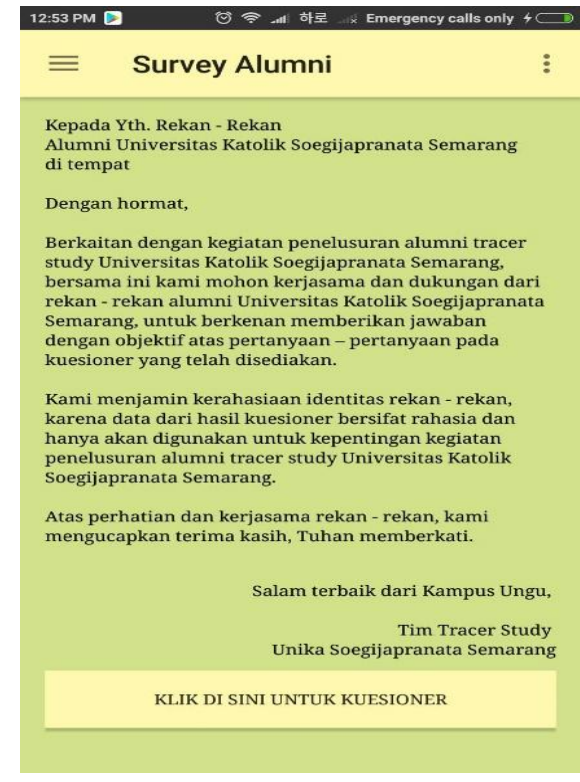

Figure 7. "Survey Alumni" Menu

Another menu is named "Digital Legalisir" facilitates alumni to legalizing the certificate or diploma by online without physically come 
to the university. This menu helps alumni who live in other city or abroad.

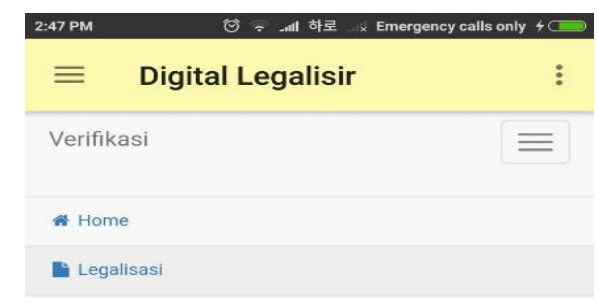

\section{Legalisasi}

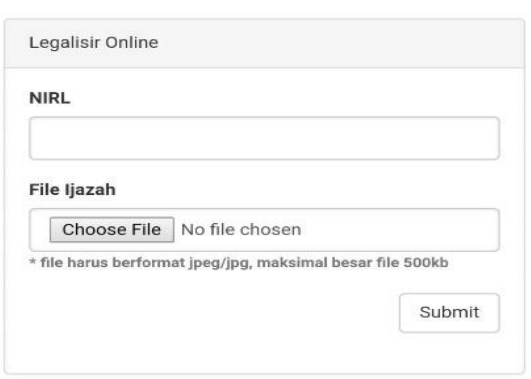

Figure 8. Digital Legalizing

Some features that exist on the application are Forgot Password and Change Password. Forgot Password facilitates user when the user cannot $\log$ in because they didn't remember their own password. There is an instruction to reset the password and the new password will be sent to the email address.

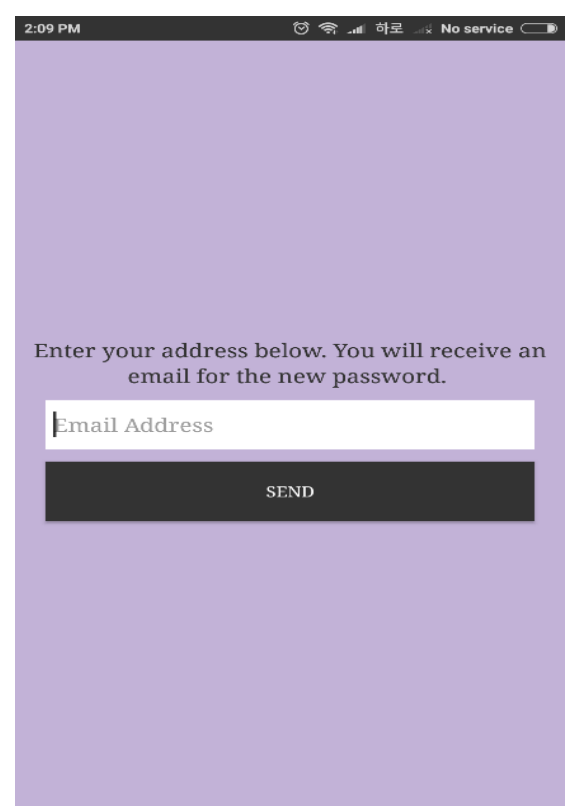

Figure 9. Forgot Password Feature

Feature Change Password facilitates user to change the account password. Old password is required to change the password, so only the right user or the owner of the account can use this feature to change the password.

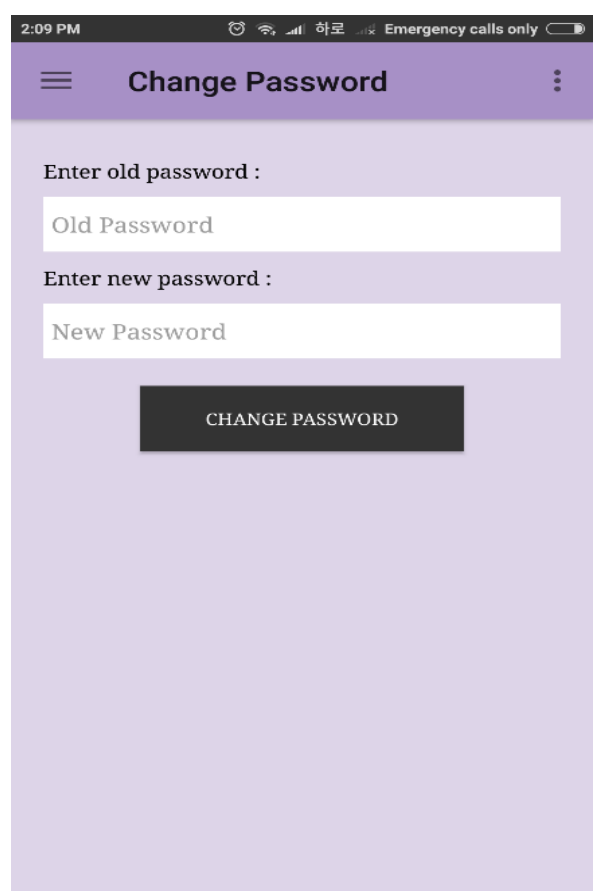

Figure 10. Change Password Feature

The last feature is routine notification. The notification is used to remind the user to check the latest vacancy. Menu Entry Level will pop up when the user taps the notification. This feature can only run well if the user gives permission to the application to AutoStart. The notification used service type and receive on complete boot, so the service will run even after the smartphone is off or rebooting.

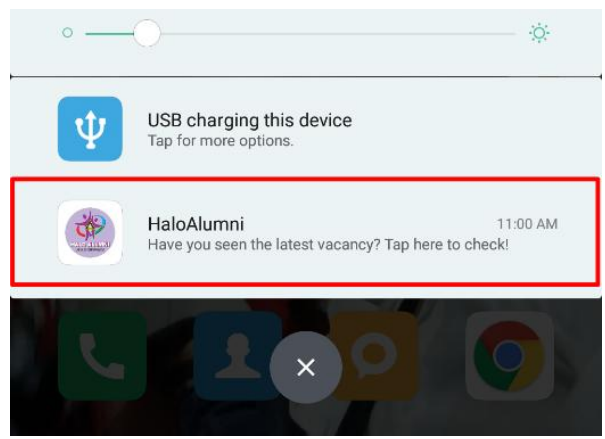

Figure 11. Notification Feature

\section{B. Questionnaire}

The title of the questionnaire is KUESIONER PENGGUNAAN APLIKASI "HALO ALUMNI" (The questionnaire of the usage of "Halo Alumni" application) and was spread in Bahasa using Google Form. Likert 
Scale was used on this survey and the questions on the questionnaire were like "How far "Halo Alumni" help you to get the information about vacancy?", "How complete the information that provided on the application?", "How good is the interface of the application?".

\section{Survey Result}

The result of the survey is 46 respondents participated to fill the questionnaire and the outcome for every question are:

1. $41.3 \%$ of respondent stated using web/gadget application every day to find the information about the vacancy. $26.1 \%$ of respondent said using web/gadget application once a month. The rest $10.9 \%$ said once a week, $13 \%$ said 2-3 weeks, and $8.7 \%$ answered never use web/gadget application in search of job information.

2. From 46 respondents, 21 respondents answered very interested in web/gadget application. $28.3 \%$ of respondent or 13 people said interested, 8 respondents said so-so, 2 respondents said not interested, and 2 respondents said very uninterested.

3. The results of the questionnaire showed that $39.1 \%$ or 18 respondents felt "Halo Alumni" helped in finding job information. $15.2 \%$ of respondents said so-so and $17.4 \%$ of respondents said the application very helpful.

4. $30.4 \%$ of the total respondents stated that job information on the application is complete. $10.9 \%$ said the information is very complete and $21.7 \%$ answered so-so.

5. $34.8 \%$ of the respondent stated that the interface of the application is good and $32.6 \%$ of respondents the interface is soso.

6. $37 \%$ of respondents answered the menus that exist in the application help them in the use of the application. 16 respondents said so-so, 6 respondents said very helpful, 5 respondents said not helpful, and 2 respondents said very not helpful.

7. $28.3 \%$ of respondents stated so-so with the features that exist in the application. 14 respondents or $30.4 \%$ answered satisfied with the features provided.
8. 21 or $45.7 \%$ respondents answered the notification feature is important. And 11 other respondents answered so-so. The remaining 7 respondents answered very important, 6 respondents answered unimportant, and 1 respondent answered very unimportant.

9. $39,1 \%$ or 18 respondents answered it is possible to use the application again in the future. 9 respondents said very possible to use the application again, 9 respondents answered so-so, and 10 respondents answered might not use the application again.

10. $17.4 \%$ or 8 respondents answered it is very possible to recommend the application to other alumni. 13 other respondents answered so-so. The remaining 16 respondents answered probably, and 9 respondents said impossible.

\section{Interview}

The interview was conducted with SSCC, in this case, the person who interviewed was Lenny Setyowati as Head of SSCC and also the leader of tracer study project. According to her, the application is able to run well, and it's already met the requirements of the initial concept. The application also helps them to spread more about the job information easily. For the graduate's data, she said that the registration method and Profile menu could be more helpful if there is a high awareness from alumni to fill the form. Not only fill once but also doing an update in the future. Another menu, Survey Alumni also helped them to spread the questionnaire easier. It proved by the total respondents that are quite high. For the last, she stated that "Halo Alumni" will be used in the next tracer study project as a tool to gain the alumni information. 


\section{CONCLUSION}

From this research, some points that come as a conclusion are:

1. "Halo Alumni" application helped the alumni, especially alumni from Soegijapranata Catholic University, to get job's information easily. That statement proved by the result of the questionnaire that state $46.4 \%$ of the respondent said the application very helpful and helpful. That percentage is greater than $25 \%$ of the respondent who said the application is not helpful. Yet, $28.6 \%$ of respondent said soso.

2. From the result of the initial interview, the features that formulated is profiled feature, a menu that consists of university's news, a feature to legalizing online, feature to send job vacancy, group discussion, and idea funding feature.

3. University has website pages that consist a lot of news. The technology that used to connect it with the application is RSS. Alumni are also able to create the feed of the RSS through menu Pasang Loker. Another website pages that offer services to alumni are connected with WebView.

4. With the registration system at the beginning of the application's flow and existence of Profile menu, the university is easier to get the data or information about the alumni. Metamorfosa menu becomes the trigger for alumni to update their data because the data is used as a basic reason to do the election of the person that will be profiled. Besides that, Survey Alumni menu also helps the university to get the information related to tracer study.

\section{REFERENCE}

[1] P. A. Soukup, "Smartphones," vol. 34, pp. 3-40, 2015.

[2] A. S, EKONOMI : - Jilid 2. Esis.

[3] Badan Pusat Statistik, "Berita Resmi

Statistik: Keadaan Ketenagakerjaan

Februari 2016," no. 46, pp. 1-6, 2016.

[4] S. Wahyudin, "Mengapa Banyak Sarjana Nganggur?," 2015. [Online]. Available: http://infomahasiswa.com/mengapabanyak-sarjana-nganggur/.

[5] D. Gray, "Smartphone Apps.," Prof. Saf., vol. 59, no. 6, pp. 46-47, 2014.

[6] "Number of Android Applications." [Online]. Available:

https://www.appbrain.com/stats/numb er-of-android-apps.

[7] "Mengenal Android Studio." [Online]. Available:

https://developer.android.com/studio/i ntro/index.html.

[8] D. Ayers and A. Watt, Beginning RSS and Atom Programming. Wiley, 2005.

[9] M. Woodman, How to Build an RSS 2.0 Feed. O'Reilly Media, 2006.

[10] K. E. Gill, "Blogging, RSS and the Information Landscape: A Look At Online News," Univ. Washingt., no. WWW 2005 workshop on the weblogging ecosystem, p. 7, 2005.

[11] J. Supranto, Statistik: Teori \& Aplikasi, Edisi 6, Jilid 1. Erlangga, 2000. 